\title{
Székely Melinda
}

\section{Ami a szavak fátyolán általtetszik A Csongor és Tünde értelmeinek (fel)fejtegetése}

A Csongor és Tünde egyik megközelítése a Bécsy Tamás által javasolt drámamodellek egyikének alkalmazása. ${ }^{1}$ Ennek alapján a Csongor és Tünde kétszintes dráma. Furcsának csak az tünik, hogy miért korlátozza magát Bécsy két szintre, holott az általa is emlegetett Shakespeare darabjaiban (például a Szentivánéji álomban) többszörös rétegződés figyelhető meg.

Fried István szintén rétegzettnek látja a darabot, de ő, a darab szövegéből kiindulva, három világot különít el, ezeket az almatő tagolja. ${ }^{2}$ Eliade alapján azt hinnénk, hogy az almatő a világ közepét jelöli, $\mathrm{s}$ általa találkoznak a függőleges tengely kozmikus szintjei: a Föld, az Eg és az Alvilág. ${ }^{3}$ Lehetne így is tagolni a darabot, szereplöit egyik vagy másik szinthez tartozónak osztani. Fried István azonban inkább müfaji világokban gondolkodik, és földinek, meseinek, illetve mitikusnak nevezi e három világot, a szereplök pedig egyszerre tartoznak mind a háromhoz.

E két értelmezés, amely kétpólusúnak, illetve hármas tagolódásúnak tekinti a Csongor és Tünde világát, nem tagadja, hanem kiegészíti egymást. A darab középponti szimbóluma azonban nem is a fa, hanem a hármas út. Az almatő csak a darab legelején és legvégén jelenik meg, idegen elemként, $\mathrm{s}$ valahogy a statikusságot jelképezi („Földben állasz mély gyököddel”4 sen szilárd ponthoz), ezzel szemben a hármas út az, amelyen a szereplők elindulnak, igazából a darab is itt indul „be”. Mivel a hármas út térként (problematikus térként) szolgál a történendőkhöz, alkalmas arra, hogy általa értelmezzük a darab tagolódását. Pócs Éva szerint a kör egyszerre jelenti a vertikális kiterjedtséget és a függőleges tengelyt. ${ }^{5}$ Ennek értelmében: a keresztút elődjét, a hármas utat a térbeli világhármasság kétdimenziós változatának tekinti. Pócs Éva valószínüleg nem gondolt a Csongor és Tündére, mikor ezt írta, megállapítása azonban érvényesíthető a darabra. Csongor kétszer lép fel a hármas útra, mind a kétszer körnek tapasztalja azt: „Tévedésnek hármas úta,/ [...] Mint varázskör áll elöttem..”, „,Oh, hármas útnak kétes ál köre."7

${ }^{1}$ Bécsy Tamás: A drámaelemzésröl. In: Tanulmányok a müelemzés köréböl. Tankönyvkiadó, Bp. 1977. 123.

${ }^{2}$ Fried István elemzésének sematikus rajza alapján a Csongor és Tünde Matúra-kiadásából, 11.

${ }^{3}$ Mircea Eliade: Le sacré et le profane. 38.

${ }^{4}$ A következőkben a Csongor és Tünde helyeire vonatkozóan csak a sor számát adom meg a Matúra-kiadás alapján (Vörösmarty Mihály: Csongor és Tünde. Gond. Kerényi Ferenc, Ikon Kiadó, Bp. 1992. Matúra Klasszikusok sorozat); az idézetek aláhúzott szavai kiemelések tőlem.

Kerényi (szerk.) 1992. 173.

${ }^{5}$ Pócs Éva: Tér és idö a néphitben. In: Ethnographia XCIV/2, 197.

${ }^{6}$ Kerényi (szerk.) 1992. 671, 687.

${ }^{7}$ Uo. 2802. 
Ismét átolvasva a Csongor és Tündét, e két értelmezés elégtelennek tetszik. Csak egy-egy, talán nem is lényeges elemet ragadnak ki, s ezt alkalmazzák a darabra. Ez talán elkerülhetetlen is. A Csongor és Tünde szövege azonban jóval többet kínál, mint ez a rétegződés. A legszembetűnőbb az, hogy ha bármilyen határ létezik is a darab világában, azon a szereplők állandóan átjárnak, s épp azáltal érzékeljük ezt, hogy látjuk őket létmódjukban megváltozni. A(z) (át)változás az, ami legtöbbször megtörténik a darabban; lehet ez metamorfózis, azaz alakváltás, de lehet egyszerü változás is, másképpen feltünés is, mint Dimitri esetében, aki rövid megjelenése alatt kétszer kandikál ki az ablakon, elöször mint a világ legszívélyesebb kocsmárosa, másodszor pedig mint pénzhajhász kereskedő jelenik meg: jellemző is Balga reakciója, amellyel válaszol e magatartásra: előbb reménykedik, majd, az elutasítás után, átkozódni kezd.

Az átváltozásnak nagyon sok változatát megtaláljuk e két pólus között, megfigyelhetjük azonban, hogy az alakváltozás inkább a női szereplőkre jellemző, akik, Ledért kivéve, mind kapcsolatban állnak a valóságon túlival. Tünde és Ilma hattyúként érkeznek, Csongor így látja őket („Hattyú szálla távol égből...”»), Ilma pedig hivalkodik is ezzel: „Már a hajnalcsillag int,/ S míg hattyúvá változom, ahhoz is csak kell idő"’. Mirígy esetében pedig még az alakváltozás is többféle, olyannyira, hogy a darab virtuális nézőjének sohasem kellene tudnia beazonosítani, az olvasónak pedig szerencséje van, mert a szöveg jelzi azt, hogy ki beszél, vagy cselekszik. S valamennyire eligazít még az, hogy a szöveg szereplöi felismerik és megnevezik Mirígyet. Erösen megkérdőjelezhető azonban, hogy az a vénasszony, akivel Csongor találkozik az első jelenetben, azonos-e azzal a személlyel, aki keresi rókává változtatott lányát, vagy azzal a kővel, amelyet a manók húznak, vagy a jósnővel. A sort folytathatnám, a szöveg mindenesetre fogódzót ad ahhoz, hogy Mirígyet személyként fogjuk fel, akinek sok minden a hatalmában van, azt is látjuk, hogy saját akaratából hogyan változik át (például kővé), gyakran közli is ezt valakivel vagy éppen velünk: „E határon/ Most én kővé változom”, , „Ott most én lakom, cselédes,/ Tiszta özvegy képiben" ${ }^{, 11}$, „Halld tehát: egy jós lakik/ Vén berek közt sziklarésben/ [...] Azt helyéböl messze úzöm,/ S én jövendölök nevében”. ${ }^{12}$

Ha viszont nem Mirígyet fogjuk fel személykét, hanem különböző alakváltozatait, akkor Mirígy csak egy projekció, a vén gonoszság belelátása különböző figurákba. Ebben az esetben Mirígy attól lesz Miríggyé, hogy valaki valakiben/valamiben felismeri öt, s ezzel mintegy megidézi. Ha Mirígy személy, akkor a darab folyamán változó erővel rendelkezik: kezdetben tehetetlen, megvénült, leláncolt asszony, később természetfeletti ereje gyakorlásával fő intrikus lesz, végezetül pedig ismét tehetetlennek látjuk. Akárcsak Prosperót a Viharban, Mirígyet is tekinthetnénk a darab belső rendezőjének, ha eltekintenénk az első és utolsó felvonástól. Ezt persze nem tehetjük meg. De nemcsak az leplezi le Mirígyet, hogy az utolsó

\footnotetext{
${ }^{8}$ Kerényi (szerk.) 1992. 185.

${ }^{9}$ Uo. 439-441.

${ }^{10}$ Uo. $1229-1230$.

${ }^{11}$ Uo. 1615-1616.

${ }^{12}$ Uo. 2308-2309, 2311-2312.
} 
felvonásban már nem fognak az átkai, és nem képes védekezni a manók ellen, ez a leleplezés ugyanis folyamatosan zajlik, attól kezdve, hogy a manók megeszik a lányát, és ő ezt nem tudja elkerülni, egész addig, hogy a pokol megtagadja tőle együttmüködését. Aki valójában képes a sorsok felett dönteni, az az Ej, Mirígy csak kontárkodik mellette.

Érdekes lesz megnéznünk, hogy ebben az összefüggésben kicsoda is Ilma valójában. Mindig Tünde társaságában jelenik meg, ezért tekinthető Tünde alteregójának. Származási különbségüknél viszont inkább egymás fordított tükörképei. Ami biztos, hogy valaminél fogva szorosan összetartoznak. Az első jelenetben magára marad, ahogy Tünde elvonul. Amikor ő is kimegy a színről, Mirígy rögtön megjelenik, megtörténik a fürtrablás, s ahogy eltünik, Ilma ismét megjelenik a színen. Majdnem ugyanazt mondja, mint Mirígy: „Mily unalmas itt az élet/ Annak, aki nem szeret." ${ }^{13}$ Jelentős még Ilma és Csongor párbeszéde, amikor Ilma sznobsága még inkább kiderül: annyira büszke tündér voltára, hogy Csongorral már alig áll szóba. A tündérség azonban nála nagyjából azonos a névcserével, meg azzal, hogy hattyúként röpködhet. Balga ezt a következőképpen reagálja le: előbb ő mesél Böskéről - „S most egyszerre szárnya nőtt,/ Mint az ájtatos közönség/ A faképnél a papot,/ Itt felejtett, itt hagyott." ${ }^{-}$, ami a szárnyat illeti, nagyon jól rátapint, bár ezt nem tudja; mikor Csongor elmondja neki, hogy jegyese tündérré változott, Balga így fakad ki: „De hogy ő is, Böske - Ilma,/ Hogy tündérré változott!/ Varjúvá tán? meglehet,/ De tündérré? nem lehet." 15 A varjú emlékeztet itt a Mirígy által emlegetett hollóra is, amelyhez az éjfélt hasonlítja, de felidézi még határozottabban Arany Vörös Rébékét. Arany balladája nyilván későbbi szöveg, de ugyanúgy a népi hiedelemvilágból merít, mint Vörösmarty, s amely szerint a varjú a boszorkány egyik megjelenési formája; azaz Balga majdnem azt mondja ki ezzel, hogy Ilma boszorkány. Az olvasó tudja, hogy Ilma mégsem varjú volt, hanem hattyú, sőt Csongor látta is ezt. Balga viszont a saját jegyeséről beszél, és ő biztosan jobban tudja, hogy ebben mi az igaz. A harmadik felvonásban Ilma úgy akar utat biztosítani maguknak, hogy megcsípi Balgát, mire Balga keresztülfekszik az úton. Közben ezt mondja: „Jaj mi szörnyű tíz köröm,/ A boszorkány körmök ilyek”, , azaz itt már azt is kimondja, hogy Ilma olyan, mint egy boszorkány, mégha teljesen nem is meri azonosítani. Meg aztán ebben a jelenetben nem tudhatja, hogy Ilmával áll szemben, mert mindkét nő le van fátyolozva. Megjegyzése emiatt is hitelesebb.

Azonkívül, hogy ki minek és milyennek látja Ilmát, ő maga is elkövet egészen „ártatlanul” egy elég súlyos vétket: ameddig asszonya költögeti Csongort, addig ő, azt hívén, hogy Balgával szerelmeskedik, az ördöggel fajtalankodik. A kifejezés nyilván erős arra a csókra, amit Ilma Kurrahtól kap, s ártatlansága épp abban áll, hogy felismerve Kurrahban a pokolfajzatot, ijedten félrevonul tőle. Az viszont a példákból nyilvánvaló, hogy Ilmában a boszorkányságra való hajlam megvan. Egyébként az öt női szereplő közül csak Tündére és az Ejre nem mondja rá senki,

\footnotetext{
${ }^{13}$ Kerényi (szerk.) 1992. 319-320.

${ }^{14}$ Uo. 869-872.

${ }^{15}$ Uo. 922-925.

${ }^{16}$ Uo. 1461-1462.
} 
hogy boszorkány, Mirígynek viszont ez a foglalkozása, Ledért pedig ő maga nevezi „csinos kis boszorkánynak”. ${ }^{17}$ Persze Ledér csak egy mindenre ('́gy bünbánatra is) képes romlott nő.

A megnevezés immár nem az átváltozás, hanem az átváltoztatás eszköze. Csongor egyetért Ilma névváltoztatásával, mivel Ilma Tünde szolgálója, a Balga által felkínált két név közül viszont már nem azt választja, amit Balga is szeretne („Árki/ Tisztességes jó nevem." ${ }^{18}$ ), ezzel dominanciáját fejezve ki Balga fölött, aki e pillanattól fogva már nem szabad ember, hanem szolga.

$\mathrm{Az}$ átváltoztatás legszebb jelenete az, amikor Balgát kicserélik a manók. „KURRAH mint utas jő szamárral Hóha, mackó, itt megálljunk,/ A bitófa vár reád. Balga derekához köti a szamarat Ezt az isten szép lovát/ Úgy cseréltem egy juhásztól/ Harminchárom birkabörön,/ $\mathrm{S}$ természet szerént: szegénytől,/ Azt is tőle loptam el./ Csillagot nem rúg, de mondják:/ Jobb szamáron, mint gyalog./ Most a szállást megtekintem,/ Addig, mackó, meg ne moccanj./ BALGA Én s bitófa! oh, te sárkány...." ${ }^{99}$ Ebben a hosszan idézett szövegben a következő megnevezések (azonosítások) fordulnak elö:

szamár = mackó, isten szép lova, (táltos), szamár

Balga $=$ bitófa

Kurrah $=$ sárkány

Azonban Kurrah elött a másik két manó is kijön, ők rendre szemétdombnak nézik Balgát, s leöntik, majd Balga a „szamárnak (= Kurrah, valójában Balga) szamarán" ${ }^{20}$ lovagol. Balga ebben a jelenetben felesleges elemként szerepel, ezért is lehet őt bárminek nézni és nevezni.

Mindennapi tetteink sem másak, mint a szóval való manipulálás eredményei, ahhoz azonban, hogy ez változásként, sőt átváltozásként ismerjük fel, olyan szervezett rendszerként való megjelenésére van szükségünk, mint ahogyan ez a Csongor és Tündében is történik: a szóval való változtatás eme mikroszkopikus esetének Mirígy vagy Tünde teljes alakváltozásai felelnek meg.

A szó ebben a formájában mágikus töltetü, ereje van, illetve az öket használó szereplők ezt hiszik. Mirígy szájában ez mindig átkot jelent, de átkozódnak a többi szereplők is. Mirígy első szava a manókhoz: „Hah, hogy átkaim kifogytak!”21 épp bevezetője egy olyan átoknak, amely megfogan, és ez rögtön láthatóvá válik. Az ö szavának sincs azonban mindig foganatja, sőt már az első jelenetben, Csongorral beszélgetve is mond néhány átkot, de azt is ő maga mondja, hogy semmit sem tehet („Áldjon isten - megboszúllak -/ E jó tétedért - megfojtlak,/ Csak tehetném!",22). A manók öröksége nemcsak a három tárgyból áll, hanem: „Mondd el a büszavakat,/ Ami rád maradt apánktól,/ És szállítsd le tolvajunkat. BERREH Tedd meg, tedd

\footnotetext{
${ }^{17}$ Kerényi (szerk.) 1992. 1742.

${ }^{18}$ Uo. 912-913.

${ }^{19}$ Uo. 1789-1800.

${ }^{20}$ Uo. 1804.

${ }^{21}$ Uo. 641.

${ }^{22}$ Uo. $153-155$.
} 
meg, az neked van/ Adva gazdag örökül."23 A szó itt még nem vesztette el erejét, e szavak jelentik a valódi örökséget, épp, mert nem lehet őket ellopni, vagy csere tárgyává tenni, mint egy következő jelenetben. A darab végére viszont ezt a szót is elvesztik, nemcsak a tárgyakat szaggatják szét közben, hanem vele együtt a szót is, amelyet aztán már meg sem említenek.

A szó tágabb értelemben nyelvként jelenik meg mint a megértés és megértetés eszköze. „Értenék csak nyelvökön!"24 - sóhajt fel Balga, mikor meg kellene szólítania a manókat, ebben a pillanatban Csongornak, meg neki is az a legnagyobb nehézsége, hogy megtalálja azt a nyelvet, amelyet majd a manók megértenek. A végül is megtalált közös nyelv azonban még nem garancia a teljes megértésre, $s$ Duzzog a szavak színeváltozását is rögtön érzékeli: „BALGA Majd igazságot teszen [Csongor]./ DuzzoG Vagy gazságot." ${ }^{25}$ Balgának még egyszer meg kell küzdeni ezzel a feladattal, amikor a beszédtilalom alatt levő tündéreket kell megszólítania. „Oh, talán nem hallotok,/ Vagy magyar szót, szép virágim,/ Még ti nem tanúltatok?"26, kérdezi Balga, s az ő szóhasználatában a magyar szó szókapcsolat jelöli a megértés nyelvét. ${ }^{27}$

A szó újabb dimenziójára vet fényt a Tudós első monológja. Elmélkedve jön, első szavai azonban inkább egy fordítás szókereső gyötrelmét mutatják, amiből aztán hamarosan a tragikus következtetésre jut: „Erő, vagy isten? milyen szó erősebb?/ Szavak, nevek, ti öltök minket el!" 28 Kezéböl kicsúszik a szavak erejének dominálása, s ez már előrejelzi azt is, amit a Tudós második megjelenésekor végső formájában látunk: a nyelv jelölésstruktúrájának zavarát. A szó keresése, görcsös keresése azt leplezi le, hogy jelölt és jelölö között nem érzi a természetes viszonyt.

A megnevezés egyben jelölés is. A jel pedig egyfajta kapcsolatteremtés záloga. Ez viszont mindig csak illuzórikusan valósul meg, a jellel nem mindig az üzenet jut el, vagy ha igen, akkor esetlegesen. Voltaképpen a legtöbb, amit a szereplök tehetnek, hogy jelet keresnek, és találnak is valamit. Csongor és Tünde kapcsolata olyan, mint Rodin $A$ csók címü szobra: a két alak csak a lábaknál, meg magában a csókban érintkezik egymással. Csongor is az első találkozás után csak elkerüli Tündét; ahhoz, hogy a végső találkozás maximálisan hasson. Mind eközben a jel az, ami közvetítene közöttük. Az első jel Ilma talányos hármasút-megjelölése. A következő jeladás épp e színhelyen történik, Ilma ötletére, aki ki is mondja, hogy Csongornak ezt a helyet jelölte ki: „Itt a hármas útelő./ Erre, mondtam, hogy menendünk./ [...] Itt az úton jelt tegyünk."29 A jel az az Ariadné-fonal, amely kivezet a rejtőzés/keresés labirintusából, de egyben maga is rejt, magába rejti azt az értelmet, amelyet hordoz. Jel és nyom azonos értelmü szavak a szövegben, de nem

${ }^{23}$ Kerényi (szerk.) 1992. 1145-1150.

${ }^{24}$ Uo. 1021.

${ }^{25}$ Uo. 1042-1043.

${ }^{26}$ Uo. 1441-1443.

${ }^{27}$ Hasonló jelenség fordul elő Balga és Ledér jelenetében; ezt részletesebben lásd Török Ervin: $A$ Csongor és Tünde kérdéseihez címú írásában (kézirat).

${ }^{28}$ Kerényi (szerk.) 1992. 771-772.

${ }^{29}$ Uo. 601-602, 604. 
véletlen, hogy a jel hordozója a homok. Nemcsak arról van szó, hogy a homok/por negatív tartalommal telítődik, hanem arról is, hogy a homok a mulandóság szimbólumaként nem válhat biztos jelhordozóvá. A nyomhagyó láb pedig ismét nem a legnemesebb testrész a jel képezésére, mégha ezt a szerelem el is feledteti.

A jelet Balga megtalálja, Csongor felismeri benne Tünde lábának nyomát. Érve viszont (,Mert kié is lenne ilyen?’30) nem igazán meggyőző, sőt a kísértés igen nagy, hogy rákérdezzünk: egy más női láb nyomát nem vette volna ugyanilyen egyértelmüen a Tünde lábanyomának, nem esetleges-e, hogy épp Tündétól származik a nyom, és épp neki, Csongornak szól? E kérdés feltevésének jogosságát megerösíti az a jelenet, amikor a lefátyolozott tündérek átballagva Balga hátán elmenekülnek, de miután Balga ismét meglátja lábuk nyomát a homokban, beazonosítja őket. Csongornak minden esélye megvan arra, hogy az élő alakban ismerje fel Tündét, mégis szükséges lehajolnia e múlékony jelhez, hogy ez megtörténjék. Csongor a fátyolos nőért ugyanúgy rajong, mint előbb Tündéért, anélkül, hogy tudja: a két alak azonos. A fátyol képes a felismerhetetlenségig elrejteni a tündéreket. Itt még hangsúlyosabb, hogy a jeladó azonossága Tündével esetleges, Csongor nem Tünde személyét keresi, hanem valamiképpen Tünde fogalmát, és neki mindegy, hogy kiben találja meg. A jelkeresés Csongornak természetes attitüdje (ezért paradox, hogy mindig Balga látja meg a lábnyomokat, dehát neki jár lennebb a szeme), alig érkezik meg a Hajnal kertjébe: „Ott, a' házba költözünk most,/ S hírt, tudósítást veszünk”31 - mondja Balgának. A hír, tudósítás itt nyilván jelet jelent, hiszen Tünde is az özvegyasszony lakánál akar Csongornak hírt hagyni. A jelkeresés többjelenetesre kinagyított változata a jóskút. A nagyítás megmutatja a jeladás törékenységét is: Ilma hiába hajít egy süteményt Balgának, az meggyúl. S bár nem a valóságot mutatják, a jósképek mégsem hazudnak: Csongor ugyan nincs a tengerparton, de néhány perccel később minden gondolkodás nélkül követi azt a nőalakot, akiről biztosan tudja, hogy Tündével nem azonos, hiszen így szólítja meg: „Álmok édes képzeménye.,

Mirígy hatalma valójában azt jelenti, hogy beavatkozik a jelek közlekedésébe, holott a darab összes szereplöje számára a jelek követése az egyetlen járható út. Az alakváltozatok kuszaságán túl az azonosságoknak a szavak szintjéig lemenő hálója is csapdába ejt(het)i a szereplőket. Az olvasót is zavarba ejti, hogy ki kicsoda, a szereplőknek viszont még ennyi fogódzójuk sincs az igazság megállapítására. Így érthető meg Csongor vaksága is, aki hol nem veszi észre Tündét, hol másban találja meg, $\mathrm{s}$ aki képes Balgát meglátni Kurrahban, illetve ezt a cserét észre nem venni. Ebben az esetben Ilma is vak, hiszen ha Csongor bagatellizálja is Balgát, Ilma sóvárog utána.

Színpadszerủvé akkor válik a darab, amikor felismerjük az átváltozásban, ami a cselekmény tulajdonképpeni építőköve, a szerepjátszást. Az ikerítés (BalgaKurrah, „Bocskor itt és bocskor ott”. ${ }^{33}$ ) és a maszk régi színházi kellékek. A szerepjátszás egy kicsit mindenkiben tetten érhető: Ilma végig megpróbálja Tündét ját-

\footnotetext{
${ }^{30}$ Kerényi (szerk.) 1992. 936.

${ }^{31}$ Uo. 1308-1309.

${ }^{32}$ Uo. 2568.

${ }^{33}$ Uo. 2248.
} 
szani, vagy legalábbis utánozni („Jer, ne lépj oly pípesen”), ${ }^{34}$ Balga szintén többször tesz kísérletet az úr-szolga-viszony megfordítására. Ha viszont Kurrah helyettesítheti Balgát, akkor ez a nőkről is elmondható. Amikor Ilma figuráját boncolgattam, arra próbáltam rávezetni az olvasót, hogy Ilma és Mirígy azonosak. Balga így fogadja Ilmát a darab végén: ,És te - ördög tudja jobban [ebben nagyon rátapint az igazságra!] - Addig merre sátoroztál,/ Hol nevettél, hol mulattál?/ Özvegyasszony képiben" 35 - az utolsó sor kísértetiesen hasonlít arra, amit Mirígy is mond magáról. Ezeket azonban nagyjából Ledérről is el lehetne mondani. Ilmát az teszi különösen érdekessé, hogy ő sohasem találkozik Miríggyel, akinek a vonásait viseli, igaz, Tünde sem. Ez csábít engem arra, hogy ha nem is azonosnak, de egy színésszel játszhatónak képzeljem el Ilma és Mirígy alakját. Ez kiemelné lényegi azonosságukat, mely a szövegben is benne rejlik, és fokozná azt a káoszt, amelyben a szereplők mozogni kénytelenek.

Alapvető szimbólummá válik gyakorisága miatt a fény, amelyet mindig Tündéhez kapcsolnak, tehát azonosnak is tekinthetők. S bár csábító, mégis nehéz fény és sötétség polaritásáról beszélni. Először is nem találnánk meg a Tünde-fénynek megfelelő sötétség pólust: ki lenne az?, talán az Éj, de hiszen Tünde igazi ellenfele Mirígy: másodszor pedig a következetes polaritás érdekében osztanunk kellene a szereplöket, ez viszont lehetetlen. Ilma ugyanis egyértelmüen Tünde árnyaként szerepel: „CSONGOR Oh, ne mondd kettőnek, egy,/ S ami ott utána megy,/ Az csak árnya termetének./ BALGA Az nekem már cifra ének!/ Hát az árnyék vastagabb-e?/ Törzsökebb-e, izmosabb-e?/ S a valóság ösztövér?/ Oh, Uram, még oly árnyékot/ Össze-vissza s átölelni/ nem legböjtibb gondolat." ${ }^{\prime 6}$ Ez az árnyékszerüség van olyan hangsúlyos, mint Tünde fényvolta. A fény devalválódása, fény és sötétség egymásba játszása az árnyékban: ezt is megtestesíti Ilma.

Még egy érv amellett, hogy itt semmiféle polaritásról nem lehet merészség nélkül beszélni: egy fény-sötétség megoszlás függőleges tengelyt alkot, de a horizontális kiterjedés ennél hangsúlyozottabb, sokkal több irányra kötelez, amelyek egymáshoz képest viszonylagosak. A viszonylagosság és bizonytalanság mindenre és mindenkire jellemző a darabban, de a darabon kívül is. Ahogy analógiák sora deríthető fel a darabban csak egy-egy szóból kiindulva is, ugyanúgy analógiás viszonyban áll a darab szövege, az általa kivetített ember (a szerint az elképzelés szerint, hogy minden szereplő Csongor személyiségének egyik összetevőjét jelképezi), a darabban levő individuumok, e szöveg olvasása, az olvasó, és az olvasó valós világa. Az analógia alapja a szerkezet, amely látszólag kaotikus, de nemcsak a múbeli világot éljük meg kaotikusnak, hanem a sajátunkat is, s valahol minden ember (fiktív és nem fiktív egyaránt) is kaotikus. Átváltozások, csalások, tévedések és rejtőzések; hasonlóságok, párhuzamok és ellentétek sürü világában élünk, de ez a világ velünk is azonos. Nemcsak azt hiszem, hogy az olvasó és a darab figurái, a „mi” valóságunk és a szövegben megjelenő világ között nincs a megjelenési formán kívül más különbség, hanem azt is, hogy az olvasás során azonosnak éljük meg a ket-

\footnotetext{
${ }^{34}$ Kerényi (szerk.) 1992. 1421.

${ }^{35}$ Uo. 3475-3478.

${ }^{36}$ Uo. 1337-1346.
} 
tőt. Ezért is nehéz világokról beszélnem, többes számban, mert vagy végtelenül sok van, vagy csak egyetlenegy; és ennek fentebb vázolt kaotikussága (s ez épp a szövegen mérhető le) tökéletes rendszerként müködik, labirintusként, amelyben a szereplők botorkálnak, de akkor is eljutnak valahova, ha ez nem eredeti, eszmei céljuk. Csongor végül megkapja Tündét, bár nem is biztos, hogy őt kereste, s Tündétől sem lehet számon kérni az önazonosságot.

A szöveg kaotikusságának müködését a motívumhálón lehet a legjobban kimutatni, amelyből csak néhány példát emelek ki. A csipkefát Ilma emlegeti elöször: „Mert, mi könnyen eshetik,/ Hogy még itt e csipkefán,/ A rokonságnak miatta,/ Fennakad csipkés ruhám. ${ }^{37}$ Ilma szavait, vagy egymást juttatják eszünkbe a következő helyek: a manók átkában: „Csipkebokron fennakadj” ${ }^{38}$, „Ej! a tüske majd megfogja./ Mondhatom, gyöngy két személy., ${ }^{39}$,Ha a csipkebokron rózsa nem teremne,/ Bolond madár volna, aki ráröppenne. ${ }^{\circ 0}$, „Ráröpült a csipkefára,/ S pillangója elveszett." ${ }^{41}$ Ugyanígy emlegetik a szereplők a boszorkánydombot, gyakran csak utalásszerủen. „Ezt a rosz kopár tető/ [...] Szülte, mint boszú jelét;/ Mert eleddig rajt' egyéb/ Rosz bogácsnál s árvahajnál/ Nem termett: azért leve/ »A boszorkánydomb « neve." ${ }^{42}$ E leírás visszhangjait halljuk a következőkben is: „Pusztább az élet, mint egy puszta domb,/ Melyen bogácsot kerget a vihar.,"43, „[Földem] terem, de nem gyümölcsöt,/ Durva tüskét, rossz csalánt,/ S háládatlan vad zabot.”, , „Puszta légy, és elvadúlt [kút],/ És vadúljon messze tőled/ Minden, ami boldog és jó.”45, „Gazdálkodni a mulékony életen,/ Imez bojtorjántermő zálogon.”46, „Alljon újólag e helyen,/ A kopárnak bámulandó/ Dísze.,"

Szándékosan nem emeltem ki olyan alapmotívumot, mint a fény, mert az asszociációk már a fenti idézetsorokban is eléggé szerteágazóak voltak, a fény esetében azonban megszámlálhatatlanok lennének. Ezek a szövegpárhuzamok teszik magát a Csongor és Tünde olvasását is kaotikussá. A legelsőt kivéve, már nem lehetséges lineáris olvasás, csak állandóan előre és visszakapcsoló, többdimenziós olvasás. Az olvasás utazásszerü volta egyet jelent labirintikus jellegével. A labirintus itt a káoszban megnyilatkozó rend metaforája. amíg a szervezőelvét nem ismerjük, addig kusza és átláthatatlan. Hogy ez a szervezőelv létezik, arra az olvasó és a szöveg között rétegződő világok azonos müködése a biztosíték, meg az, hogy mindegyikben otthon vagyunk: hogy bár a szöveg már bennünk van, olvasása mégis gyönyör marad.

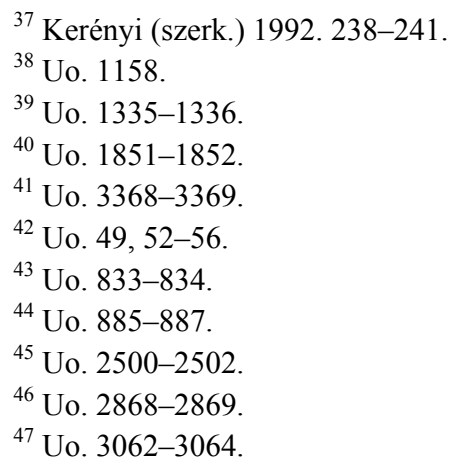

